University of Michigan Law School

University of Michigan Law School Scholarship Repository

\title{
No Link: The Jury and the Origins of the Confrontation Right and the Hearsay Rule
}

\author{
Richard D. Friedman \\ University of Michigan Law School
}

Available at: https://repository.law.umich.edu/book_chapters/211

Follow this and additional works at: https://repository.law.umich.edu/book_chapters

Part of the Common Law Commons, Criminal Procedure Commons, and the Evidence Commons

\section{Publication Information \& Recommended Citation}

Friedman, Richard D. "No Link: The Jury and the Origins of the Confrontation Right and the Hearsay Rule." In "The Dearest Birth Right of the People of England": The Jury in the History of Common Law, edited by J. W. Cairns and G. McLeod, 93-100. Portland, Oreg.: Hart Pub., 2002.

This Book Chapter is brought to you for free and open access by the Faculty Scholarship at University of Michigan Law School Scholarship Repository. It has been accepted for inclusion in Book Chapters by an authorized administrator of University of Michigan Law School Scholarship Repository. For more information, please contact mlaw.repository@umich.edu. 
6

\title{
No Link: the Jury and the Origins of the Confrontation Right and the Hearsay Rule
}

\author{
RICHARD D FRIEDMAN (ANN ARBOR)*
}

The rule against hearsay has long been one of the most distinctive elements of the common law of evidence, and indeed-except for recent changes on the civil side in many jurisdictions-of the common law system of trial. Observers have long believed that the rule, like most of the other exclusionary rules of the common law of evidence, is "the child of the jury system". ${ }^{1}$ Though Edmund Morgan argued vigorously to the contrary, ${ }^{2}$ the received understanding is that the jury's inability to account satisfactorily for the defects of hearsay explains the rule. ${ }^{3} \mathrm{~A}$ famous, and perhaps seminal, expression of this view was that of Chief Justice Mansfield in Re Berkeley:

"[I]n England, where the jury are the sole judges of the fact, hearsay is properly excluded, because no man can tell what effect it might have upon their minds". ${ }^{4}$

In recent years, the abolition of the hearsay rule as a doctrine of exclusion in civil litigation in Britain has been predicated on the near-total absence of the

\footnotetext{
* This paper is largely based on research I have been doing with Mike Macnair. I am, however, responsible for the contents of this paper and any mistakes in it.

1 This is the celebrated term applied to the law of evidence in general in J B Thayer, $A$ Preliminary Treatise on Evidence at the Common Law (Boston, Little, Brown, 1898), 266, based in part on the danger that the evidence is "likely to be misused or overestimated by that body".

2 "The essays of the great Thayer, the rationalisations of the judges beginning in the third or fourth decade of the 19th century and the acceptance of these by Wigmore have combined to make orthodox the fallacy that the exclusionary rules of evidence, and particularly, the hearsay rule, are results of the jury system." Foreword to American Law Institute, Model Code of Evidence (Philadelphia, American Law Institute, 1942), at 36.

3 See C Tapper, "Hearsay in Criminal Cases: An Overview of Law Commission Report No. 245", [1997] Crim LR 771 at 777 and n. 43.

44 Camp. 401 at 415,171 ER 128 at 135 (1811). Mansfield distinguished the situation in Scotland, where judges were the finders of fact, and could "trust themselves entirely" to give hearsay such weight as they thought it deserved.
} 
jury from such litigation. ${ }^{5}$ Colin Tapper, a highly sophisticated scholar of evidence, has expressed the perplexity that:

"[W]hile the absence of a jury from most modern civil proceedings has been a major contributory factor to the separate development of the hearsay rule in civil and criminal proceedings, the comparable difference between summary proceedings and trials on indictment within the area of criminal proceedings has failed to lead to a comparable separation of development". ${ }^{6}$

Even on its face, this emphasis on the role of the jury in explaining the hearsay rule is a rather curious one: there is no reason to believe that, as a general matter, the jurors will so over-value hearsay that the truth-determination process is improved by shutting their ears to it. Indeed, the empirical evidence suggests that jurors tend to under-value hearsay. ${ }^{7}$ More fundamentally, this view ignores history, which demonstrates rather clearly that at the core of the hearsay rule is the funda mental right of a litigant, especially a criminal defendant, to confront the witnesses against him. This right has a scope much narrower than the modern rule against hearsay, and it does not explain or justify all of hearsay law. But it has roots that are deep and broad. It is one of the cornerstones of the common law system of adjudication, and it is not substantially affected by whether or not the trier of fact is a jury.

Any adjudicative system based on evidence must determine how witnesses are to give evidence. A particularly common requirement, one shared by the common law as well as many systems that do not rely on a jury, is that a witness testify under oath. And throughout history many systems, whether they use the jury or not, have required that a witness give testimony in the presence of the accused. Thus, in Acts, 25.16, the Roman governor Festus declares:

"It is not the manner of the Romans to deliver any man to die, before that he which is accused have the accusers face to face, and have licence to answer for himself concerning the crime laid against him."

Here we see an early, but quite clear, expression of the confrontation right: when a witness testifies, she must do it "face to face" with the accused, pre-

\footnotetext{
5 Civil Evidence Act 1995, s. 1, which provides that "[i]n civil proceedings evidence shall not be excluded on the ground that it is hearsay", resulted from a recommendation by the Law Commission for England and Wales, which emphasised "the greatly reduced use of juries in civil trials other than for defamation proceedings". The Law Commission for England and Wales, The Hearsay Rule in Civil Proceedings, Consultation Paper No. 117 (London, HMSO, 1991), 52. The 1995 Act was foreshadowed by a similar development in Scotland. See Civil Evidence Act, 1988, c. 32, s. 2 (abolishing the rule against hearsay in civil cases); Scottish Law Commission, Evidence: Report on Corroboration, Hearsay and Related Matters in Civil Proceedings, Report No 100 (Edinburgh, HMSO, 1986), 16-17 (emphasising the limited use of the civil jury), 23 (recommending the abolition of the rule against hearsay).

6 Tapper, supra n. 3, 777.

7 P Miene, R C Park and E Borgida, "Juror Decision Making and the Evaluation of Hearsay Evidence", (1992) 76 Minnesota LR 683.
} 
sumably in front of the trier of fact. It is not acceptable for her to testify through intermediaries.

This confrontational method of giving testimony has not been universal. To minimise the dangers of intimidation, traditional Continental systems took testimony out of the presence of the parties, though they protected the right of cross-examination through written interrogatories. But this was not the English norm. In the middle of the sixteenth century, Sir Thomas Smith described the heart of a criminal trial as an open "altercation" between accuser and accused. ${ }^{8}$ And repeatedly, over hundreds of years, English judges and commentators declared the superiority of English law in this respect. For example, in the Case of the Union of the Realms, Lord Chief Justice Popham, arguing for the superiority of English over Scots law, contended that "the Testimonies, being viva voce before the Judges in open face of the world", were "much to be preferred" over "written depositions in a corner".?

To be sure, even in England, the norm of confrontation was not always followed. But the situations in which it was not followed reveal the strength and ultimate triumph of the principle that testimony must be given in the presence of the adverse party-and the irrelevance of the jury to that norm.

First, the common law courts shared an uneasy coexistence with the courts of equity and other courts that followed Continental procedures. One advantage of those procedures was that a deposition could preserve the testimony of a witness if the witness was unable later to testify at trial. Common law courts came to accept these depositions as a second-best alternative to trial testimony in the case of an unavailable witness. Indeed, by the middle of the seventeenth century the courts developed a sophisticated body of law determining when depositions were acceptable and ensuring that a deposition could not be used as evidence unless the adverse party had an adequate opportunity of cross-examination through written interrogatories. ${ }^{10}$ Thus, Sir Geoffrey Gilbert, commenting in the first years of the eighteenth century on a case from several decades earlier, wrote:

"A Deposition can't be given in Evidence against any Person that was not Party to the Suit, and the Reason is, because he had not Liberty to cross-examine the

8 T Smith, De Republica Anglorum, ed. by M Dewar (Cambridge, University Press, 1982), Bk 2, ch. 15 .

${ }_{9}$ Moore (KB) 790 at 798, 72 ER 908 at 913 (1604). See also, e.g., S Emlyn, Preface to State Trials (London, J Walthoe, Sen., 1730); M Hale, History of the Common Law, ed. by C M Gray (Chicago, University of Chicago Press, 1971), 163-4; W Blackstone, Commentaries on the Laws of England (Oxford, Clarendon Press, 1765-69), vol. 3, *373.

10 Fortescue v. Coake, Godb. 193, 78 ER 117 (Com. Pleas, 1612); Anon., Godb. 326, 78 ER 192 (KB 1623); Rushworth v. Countess de Pembroke ó Currier, Hardres 472, 145 ER 553 (1668). This law developed more rapidly and systematically in civil cases. This disparity presumably occurred in part because of the presence of counsel in civil cases and in part because of the use, discussed in the text below, in criminal cases of examinations taken before magistrates. 
Witnesses, and 'tis against natural Justice that a Man should be concluded in a Cause to which he never was a Party". ${ }^{11}$

Similarly, magistrates acting pursuant to statutes passed in the reign of Queen Mary took statements from accusing witnesses in felony cases. It seems rather clear that the expectation, and at least the usual practice, was for the accused to be present when this accusatory statement was taken. ${ }^{12}$ Quickly, the practice arose of taking these statements under oath, the understanding being that doing so would preserve the testimony for use at trial if the witness died beforehand. As William Lambarde, writing a manual for justices of the peace in 1581, explained:

"[I]f these informers bee examined upon Oath, then although it should happen them to die before the Prisoner have his Triall, yet their information may bee given in evidence, as a matter of credite, whereas otherwise it wold be of little or no weight at all, \& therby offenders shold the easlier escape unpunished". ${ }^{13}$

It was clear that, if the accuser was not dead, or unable to travel, or put out of the way by the accused, this pre-trial statement could not be used; the witness must testify live at the trial. ${ }^{14}$ And in 1696 , the justices of the Courts of King's Bench and of Common Pleas determined after a consultation that this practice should not be extended to misdemeanour cases, where it was not supported by tradition and statutory authority - and they did so specifically on the basis that:

"the defendant not being present when [the statements] were taken before the [examining authority, in this case the mayor], and so had lost the benefit of a cross-examination". ${ }^{15}$

Finally, of great significance was the practice in treason cases and other politically charged trials. The Crown, eager to use the criminal law as a

11 G Gilbert, The Law of Evidence (London, 1754), 47. Mike Macnair has dated the writing of the treatise, which was published long after Gilbert's death, to the first decade of the century.

12 The statutes required the magistrate to take a statement from the accused as well as from the person who brought him in, so the statements were presumably taken in close time proximity. Professor J M Beattie, who has studied the reports of these statements extensivelythough without addressing this question-says that the accused's familiarity with the accusatory statement appears to be a presupposition of the accused's statement.

13 W Lambarde, Eirenarcha: or Of the Office of the Justices of Peace 210 (London, Imprinted by Ra. Newbry and $\mathrm{H}$ Bynneman, by the ass. of Ri. Tot[ell] \& Ch. Bar[ker], 1581), quoted in J H Langbein, Prosecuting Crime in the Renaissance: England, Germany, France (Cambridge, Mass. Harvard University Press, 1974), at 27. The principal statute, $1 \& 2 \mathrm{Ph}$. \& M., c. 13, required examination of those that "bring" the accused; it did not refer explicitly to accusing witnesses, and most often it was the constable who brought the accused to the justice of the peace. But it appears that the constable was usually accompanied by the accusing witnesses, and this was the practice recommended by Lambarde-presumably because of the opportunity it offered for preserving testimony. See Langbein, supra, at 11-12.

14 See the notes following $R$ v. Paine, 1 Salk. 281, 91 ER 246 (1696).

$15 R$ v. Paine, 5 Mod. 163 at 165,87 ER 584 at 585. 
means of controlling its adversaries, sometimes used testimony taken out of the presence of the accused. Thus, it is in the treason cases of the Tudor and Stuart period that the battle for the confrontation right was most clearly fought. As early as 1521, treason defendants, often using the term "face to face", demanded that the witnesses be brought before them. ${ }^{16}$ Sometimes these demands were heeded, ${ }^{17}$ sometimes not-but what is most notable is that they found recurrent support in acts of Parliament, which repeatedly required that accusing witnesses be brought "face to face" with the defendant. ${ }^{18}$ By the middle of the seventeenth century, the battle was won, and courts clearly understood that treason witnesses must testify before the accused, subject to questioning by the accused. ${ }^{19}$

Well into that century, prosecutorial authorities often tried to use confessions of alleged accomplices of the accused that were not made according to the usual norms of testimony, under oath and before the accused. The case of Sir Walter Raleigh is the most notorious, but far from the only one. The theory was that self-accusation was "as strong as if upon oath". ${ }^{20}$ But the judges soon realised the iniquity of allowing an exception to the usual norms of testimony simply because the accomplice accused himself as well as another. ${ }^{21}$ In 1662 , shortly after the Restoration, the judges of the King's Bench ruled unanimously and definitively that,

16 E.g., Seymour's Case, 1 How. St. Tr. 483 at 492 (1549); Duke of Somerset's Trial, 1 How. St. Tr. 515 at 520 (1551).

17 According to E Hall, The Union of the Two Noble and Illustre Famelies of Lancastre \& Yorke (London, 1548), published under the title Hall's Chronicle (London, J Johnson, 1809), 623 , the witnesses against the Duke of Buckingham in 1521 were produced at his request. Hall's account of Buckingham's trial appears to be the ultimate source for the one offered by Shakespeare and Fletcher in King Henry VIII, II,i. John Spelman, a justice of the King's Bench, was careful to note in his report of a treason trial of 1531 that the accuser confronted the defendant "face to face." $R$ v. Rice ap Griffith, in The Reports of Sir John Spelman, ed. by J H Baker, Seld. Soc., vol. 93 (London, 1976), vol. 1, 47.

$185 \& 6$ Edw. VI, c. 11 , s. 9 (1552), and $1 \& 2$ P. \& M., c. 10, s 11 (1554), required witnesses to be "brought forth in person" before the accused. 1 Eliz. I, c. 1, s. 21 (1558), 1 Eliz. I, c.5, s. 10 (1558), 13 Eliz. I, c. 1, s. 9 (1571), and 13 Car. II, c.1, s. 5 (1661), all used the "face to face" formulation.

19 For example, in the celebrated case of John Lilburne in 1649, there was no doubt that the witnesses would testify live in front of Lilburne; "hear what the witnesses say first," said the presiding judge in postponing one of Lilburne's arguments: 4 How. St. Tr. 1270 at 1329 . When the witnesses did testify, Lilburne was allowed to pose questions to them, through the court: ibid. at 1333, 1334, 1335, 1340. In John Mordant's Case, just nine years later, there does not seem to have been any doubt that he could question the witnesses directly, which he did, 5 How. St. Tr. 907 at 919-21. Indeed, at one point the presiding judge solicitously inquired whether Mordant wished to ask a witness any questions, ibid. at 922 , a practice that soon became routine: e.g., Colledge's Case, 8 How. St. Tr. 549, at 599, 603, 606 (1681).

${ }^{20}$ Earl of Somerset's Case, 2 How. St. Tr. 966 at 986 (1616) (Coke, CJ).

21 In 1631, the judges concluded that, at the trial of a peer before the House of Lords, "[c]ertain Examinations [clearly confessions from the context] having been taken by the lords without an oath ... could not be used until they were repeated upon oath." Lord Audley's Case, 3 How. St. Tr. 401 at 402 (1631). 
though a pre-trial confession was "evidence against the Party himself who made the Confession" and, if adequately proved could indeed support conviction of that person without witnesses to the treason itself, the confession "cannot be used as evidence against any others whom on his Examination he confessed to be in the Treason". ${ }^{22}$ This fundamental principle quickly became canonical. ${ }^{23}$

Thus, there was a clear-though not entirely uncluttered-norm that guided English civil and criminal trials, that witnesses should give their testimony in open court, face to face with the adverse party. Nowhere in the development of this norm of confrontation does any deficiency on the part of the jury appear to have been mentioned. The concern was not the jury's inability to deal with secondary evidence but rather the fact that such evidence did not conform to proper procedural conceptions. And only ra rely was such evidence referred to as hearsay. As is apparent from Gilbert's perfunctory treatment, hearsay had a limited meaning, one conforming closely to what even now is probably the common lay understanding of the term - a witness's account of what another person had said. Even quite late in the eighteenth century, the term hearsay would not have been used to refer to written transcriptions of previously taken testimony, or indeed to other writings offered as evidence. ${ }^{24}$

Furthermore, the norm of confrontation did not extend the full breadth of the modern legal conception of hearsay. Under that conception, hearsay is any statement made out of court and offered to prove the truth of a matter that the statement asserts. The confrontation norm, however, was a principle that governed the procedures for the giving of testimony. Around the beginning of the nineteenth century, probably because of the growing role of lawyers in criminal trials, courts and treatise writers became far more sensitive to the absence of cross-examination with respect to out-of-court statements that were not made for the purpose of giving testimony. Hearsay became the rubric under which this concern was expressed, and the category of hearsay expanded to include writings. ${ }^{25}$ Almost inevitably, then, the

22 Case of Thomas Tong and Others, Kelyng 17 at 18, 84 ER 1061 at 1062 (1662).

${ }^{23}$ See Gilbert, supra n. 11, 99; W Hawkins, A Treatise of the Pleas of the Crown (London, printed by Eliz. Nutt and R Gosling, assigns of Edward Sayer for J Walthoe jun., 1721), vol. 2, 429.

24 Cf. F Buller, An Introduction to the Law Relative to Trials at Nisi Prius (London, printed by W Strahan and $M$ Woodfall for $C$ Bathurst 1772), 235-6 (saying that depositions can be admitted "in general in all Cases where Hearsay and Reputation a re Evidence; for undoubtedly what a Witness, who is dead, has sworn in a Court of Justice, is of more Credit, than what another Person swears he has heard him say").

${ }_{25}$ T Peake, A Compendium of the Law of Evidence (London, $\mathrm{E}$ and $\mathrm{R}$ Brooke and J Rider, $1801), 10$. Peake says, in the course of his discussion of hearsay, that certain written memoranda made in the ordinary course of business are admissible as "not within the exception as to hearsay evidence". The backhand suggestion appears to be that other writings would be "within the exception" - that is, objectionable as hearsay. By 1815, S M Phillipps made the principle clear: The exclusionary rule "is applicable to statements in writing, no less than to 
hearsay rule also expanded to include the long-established rules governing when depositions of a witness, taken under oath before trial, could be introduced in lieu of trial testimony. ${ }^{26}$ And eventually the expansion included conduct that did not assert the proposition at issue but appeared to reflect the actor's belief in it. ${ }^{27}$ Now the modern shape of the hearsay rule was complete. ${ }^{28}$

The expansions that yielded this form of the rule could not all be justified on the basis of the need to protect the conditions under which testimony is given, because conduct that was ante litem was not testimonial in nature. Perhaps for this reason, it is in this same era that we first see the justifications for the hearsay rule being laid at the feet of the jury. The analysis here suggests, however, that the jury had very little to do with the development of the hearsay rule. Nor should it have much to do with the question of whether, or in what form, the rule ought to be retained.

On the one hand, at the core of the hearsay rule is a noble principle that it is critical to preserve. This principle is the confrontation norm-the requirement that a witness must testify openly, in the presence of the accused and subject to cross-examination. The modern hearsay rule is too poorly articulated, too broad, and too riddled with exceptions to protect that principle ideally well. Not only does the principle remain valid, however; it may be considered a fundamental aspect of fair criminal procedure, whether a jury is present or not. Indeed, in a highly ironic development, the European Court of Human Rights-operating outside the context of a system that has either the jury or hearsay law-has recognised the significance of the confrontation right and issued a series of decisions protecting it. ${ }^{29}$

On the other hand, to the extent that the hearsay rule excludes evidence where the confrontation norm is not at stake-for example, statements made ante litem - the justification for the rule seems dubious. Certainly the rule has significant costs, most notably in the loss of valuable information to the truth-determining process. Perhaps other justifications, such as the creation of incentives to present live testimony, justify limited application of an exclusionary rule. But whether this is true or not, the presence or absence of the jury as trier of fact should have very little bearing. Perhaps in time there will be persuasive reason to believe that juries tend to over-value hearsay

words spoken", the only difference in this respect being that there is greater facility of proof in the case of writings than of oral statements: S M Phillipps, A Treatise on the Law of Evidence (New York, Gould, Banks and Gould, 1816), vol. 1, 173. Phillipps' analysis does not appear to have gained immediate universal acceptance.

26 Phillipps, supra n. 23, 177-8 (discussing the celebrated Berkeley case, 4 Camp. 401, 171 ER 127 (1811)).

27 Wright v. Tatham, 5 Cl. \& F. 670, 7 ER 559, 47 Rev. Rep. 136 (HL 1838).

28 See, for example, the quite modern-sounding explanation in T Starkie, A Practical Treatise on the Law of Evidence (Boston, Wells and Lillie, 1826), vol. 1, 47 (Pt. I, \$28).

29 E.g., Van Mechelen v. Netherlands, 25 EHRR 647 (1998). 


\section{Richard D Friedman}

evidence by so much that truth-determination is advanced by shutting their eyes and ears to such evidence. I doubt it, though, and until such time the jury-defect theory should be considered as nothing more than an unsupported rationale accepted unquestioningly in a bygone era. ${ }^{30}$

${ }^{30}$ See supra n. 7. 